\title{
Geologic Features of Areas of Abnormal Radioactivity South of Ocala Marion County, Florida
}

GEOLOGICAL SURVEY BULLETIN 1046 -J

This report concerns work done on behalf of the U. S. Atomic Energy Commission and is published with permission of the Commission 



\section{Geologic Features of Areas}

of Abnormal Radioactivity

South of Ocala

Marion County, Florida

$B y$ GILBERT H. ESPENSHADE

CONTRIBUTIONS TO THE GEOLOGY OF URANIUM

GE OLOGICAL S U R VEY B U L LE T I N $1046-\mathrm{J}$

This report concerns work done on behalf of the U.S. Atomic Energy Commission and is published with permission of the Commission

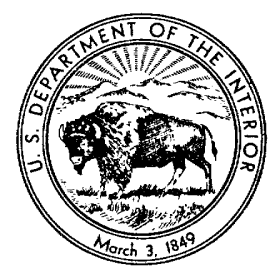


UNITED STATES DEPARTMENT OF THE INTERIOR

FRED A. SEATON, Secretary

GEOLOGICAL SURVEY

Thomas B. Nolan, Director

For sale by the Superintendent of Documents, U. S. Government Printing Office Washington 25, D. C. - Price $\$ 1.00$ (paper cover) 


\section{CONTENTS}

\begin{tabular}{|c|c|}
\hline & Page \\
\hline Abstract & 205 \\
\hline Introduction & 205 \\
\hline Radioactivity anomalies & 206 \\
\hline Geology & 206 \\
\hline Stratigraphy & 206 \\
\hline Ocala limestone & 206 \\
\hline Miocene sedimentary rocks & 207 \\
\hline Pleistocene sediments & 209 \\
\hline Structure & 210 \\
\hline Effects of weathering & 210 \\
\hline Drilling and sampling methods. & 211 \\
\hline Uraniferous phosphatic materials. & 212 \\
\hline Pellet phosphorite & 212 \\
\hline Clay & 216 \\
\hline Leached phosphorite & 216 \\
\hline Conclusions & 218 \\
\hline References cited & 219 \\
\hline
\end{tabular}

\section{ILLUSTRATIONS}

[Plates are in packet]

Plate 12. Radioactivity anomalies south of Ocala.

13. Longitudinal sections and plan of auger drill holes 21-24.

14. Longitudinal sections of auger drill holes 25-29.

15. Longitudinal sections of auger drill hole 30 .

\section{TABLES}

TABLE 1. Uranium, $\mathrm{P}_{2} \mathrm{O}_{5}$, and quartz contents of different size fractions of samples of pellet phosphorite from drill holes

2. Uranium, $\mathrm{P}_{2} \mathrm{O}_{5}$, and quartz contents of samples of pellet phosphorite from the same (?) bed in four different drill holes..--

3. Uranium, $\mathrm{P}_{2} \mathrm{O}_{5}$, and quartz contents of samples of clay from

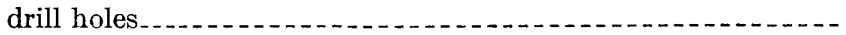

4. Uranium, $\mathrm{P}_{2} \mathrm{O}_{5}, \mathrm{Al}_{2} \mathrm{O}_{3}, \mathrm{CaO}$, and quartz contents of samples of leached phosphorite from surface outcrops and float.........-

5. Uranium, $\mathrm{P}_{2} \mathrm{O}_{5}, \mathrm{Al}_{2} \mathrm{O}_{3}, \mathrm{CaO}$, and quartz content of samples of leached phosphorite from drill holes. 



\title{
CONTRIBUTIONS TO THE GEOLOGY OF URANIUM
}

\section{GEOLOGIG FEATURES OF AREAS OF ABNORMAL RADIOACTIVITY SOUTH OF OCALA, MARION COUNTY, FLORIDA}

\author{
By Gilbert H. Espenshade
}

\begin{abstract}
Areas of abnormal radioactivity south of Ocala, Marion County, Fla., discovered in 1953 by aerial survey, were investigated by surface examination and by 10 power-auger drill holes. Interbedded clay, elayey sand, and uraniferous phosphorite occur in the areas of anomalous radioactivity. Miocene fossils occur at 3 localities in these beds which are evidently outliers of Miocene sedimentary rocks on the Ocala limestone of Eocene age. The preserved outliers are southwest of the main belt of Miocene sedimentary rocks.

The principal uraniferous rocks are clayey, sandy, pellet phosphorite that occurs in beds a few feet thick, and very porous phosphatic sand rock that makes abundant float at many places. Apatite forms the phosphate pellets in the unweathered phosphorite. The very porous phosphatic sand rock is the highly leached residuum of the pellet phosphorite and is composed mainly of quartz, kaolinite, wavellite, and crandallite (pseudowavellite). It closely resembles the aluminum phosphate rock of the "leached zone" of the Bone Valley formation of Pliocene age in the land-pebble phosphate district.
\end{abstract}

\section{INTRODUCTION}

The geology of some areas of abnormal radioactivity south of Ocala, Marion County, Fla., was investigated as part of the Geological Survey's program of study of uraniferous phosphate deposits on behalf of the Division of Raw Materials of the U. S. Atomic Energy Commission. These anomalies had been discovered by the Geological Survey in 1953 in the course of aerial reconnaissance for uraniferous phosphate deposits (Moxham, 1954). One of the anomalous areas was examined at that time, and several other anomalies were later explored by means of a jeep-mounted power auger (Cathcart, 1954). The writer and L. A. Brubaker examined most of the anomalous areas in March 1955, and put down 10 drill holes at 3 localities with a power auger. Samples were taken for chemical analysis and mineralogic study, and the drill holes were logged with a portable scintillation gamma-ray logger. 
The writer is grateful for the contributions made to this study by L. A. Brubaker during the fieldwork and by other colleagues of the Geologic Survey.

\section{RADIOACTIVITY ANOMALIES}

The occurrence of phosphate in this area had previously been reported by Matson (1915, pl. 3), and Cooke (1945, p. 158-159, pl. 1), who recognized outliers of phosphatic Hawthorn formation of Miocene age resting upon the Ocala limestone, and by various prospectors (Cathcart, J. B., written communication, 1955). For this reason the area was one of ten in Florida selected by J. B. Cathcart for airborne radioactivity survey. The aerial survey was made with scintillationdetection equipment by flying parallel traverse lines, a quarter of a mile apart, at about 500 feet above the ground (Moxham, 1954). Irregular areas of abnormal radioactivity were found between Ocala and Summerfield, which is about 13 miles southeast of Ocala (pl. 12). The average background radioactivity here, presumably over Ocala limestone, was about $1 \mu \mathrm{r}$ per hour (microroentgen per hour) at 500 feet above the ground; the highest anomalies recorded reached a maximum of $11 \mu \mathrm{r}$ per hour. ${ }^{1}$ Moxham (1954) points out that the anomalies seem to conform more or less to outliers of the Hawthorn formation, shown on the state geologic map by Cooke (1945). Several small areas of high radioactivity found during the geologic investigation are shown on plate 12 ; these evidently lie between the flight lines of the aerial survey. The area was not completely covered by ground examination, and it is possible that other small anomalies exist which were not detected.

\section{GEOLOGY \\ STRATIGRAPHY \\ OCALA IIMESTONE}

The Ocala limestone of late Eocene age is the oldest formation exposed in the region, and exposures are scarce. Beds a few feet thick crop out in some sinkholes, but the formation is best exposed in abandoned quarries in the area covered by plate 12, and in active quarries a few miles to the north of the map area. The Ocala limestone presumably lies beneath a thin mantle of soil and sand in nearly all the area shown in plate 12 except the areas of anomalous radioactivity.

The Ocala limestone is very fossiliferous, soft, porous, and white to cream; weathered surfaces are bluish gray. This limestone is

1 These values have been corrected from the values originally reported by Moxham (1954), namely $0.25 \mu \mathrm{r}$ per hour for average background radioactivity and $2.75 \mu \mathrm{r}$ per hour for maximum radioactivity, which were found by later calibration tests to be too low (Moxham, written communication, 1955). 
characteristically almost pure and contains very little insoluble material. Light-gray chert containing silicified fossils occurs in lenticular masses that extend along the bedding and are a few inches to several feet thick.

\section{MIOCENE SEDIMENTARY ROCKS}

Within the areas of abnormal radioactivity, the Ocala limestone is overlain by beds of clay, sandy clay, and sand. Phosphate pellets are abundant in some layers. These layers are exposed in only a very few places, but float of phosphate pellets, sandy phosphorite, and leached porous phosphorite is found at various places in the areas of abnormal radioactivity. Information about the detailed stratigraphy and lithology of these beds is derived mainly from the logs of the auger drill holes (pls. 13, 14, and 15). Beds composed largely of clay alternate with sandy beds that contain moderate amounts of clay; phosphate pellets are larger and more abundant in some sandy beds than in clay. The thickest sequence of beds presumed to be of Miocene age, nearly 65 feet, was cut in drill hole 28 (pl. 14); a thickness of $58 \frac{1}{12}$ feet of beds assigned to the Miocene was cut in drill hole 30 (pl. 15).

Fossils of Miocene age were found on the surface at 3 localities within areas of radioactivity anomalies. Hard white sandy limestone with small phosphate pellets is exposed in slumped beds about 5 feet thick in a small pit about 200 feet northeast of drill hole 21 (fossil-collecting locality 63, pl. 13). Similar fossiliferous limestone occurs as float and low ledges along the roadbed at fossil-collecting locality 108, about 9 miles to the northwest of locality 63 (pl. 12); silicified oysters, shark teeth, manatee ribs, and abundant phosphate pellets are scattered over the surface here. Druid Wilson of the U. S. Geological Survey considered the fossils at these two localities to be of early or middle Miocene age; his report (written communication, 1955) on these fossils collections is quoted below.

Locality $63-\mathrm{NW} / 4$ SW 34 sec. 2 , T. 17 S., R. 22 E., Marion County, Fla.

Fossiliferous sandy phosphatic limestone 5 feet below surface in small pit about 15 feet deep.

Foraminifera:

"Sorites" sp.

Pelecypoda:

Modiolus ef. $M$. curtulus Dall

Cyrena? sp.

Macrocallista ef. M. floridana (Conrad)

Chione (Lirophora) sp.

Venus ef. V. halidona Dall

Venus ef. V. marionana Dall

Dosinia ef. D. chipolana Dall 
Gastropoda:

Pleurodonte ef. $P$. kendrickensis Mansfield

Bulimulus sp.

Uzita cf. U. paraprista Gardner

Calyptraea aperta (Solander)

Locality 108-Along dirt road, about 0.6 miles northeast from junction (in NE 34 sec. 35, T. 15 S., R. 21E.) with Shady Lane road, Marion County, Fla.

Foraminifera:

"Sorites" sp.

Pelecypoda:

Chama ef. C. draconis Dall

Chione ef. C. trimeris Gardner

Dosinia sp.

Gastropoda:

Pleurodonte sp.

Bulimulus sp.

Calyptraea aperta (Solander)

Other marine genera of mollusks which cannot be identified specifically might be listed from both localities 63 and 108.

Age (Localities 63 and 108): early or middle Miocene.

The collections from localities 63 and 108 apparently represent the same fauna from Marion County referred by Mansfield (1937, Fla. Geol. Survey Bull. 15, p. 23) to the Tampa limestone. It should be pointed out that none of the distinctive Tampa genera was listed by Mansfield nor do they occur in the present collection. Land snails of the genera Pleurodonte and Bulimulus are common in the two collections but this cannot be regarded as proof that the fauna is of early Miocene (Tampa) age, although land snails have not been reported in Florida either in the Oligocene or later than Tampa of Miocene age. Some species, as indicated by Mansfield (p. 24) and some in the present collection suggest an age younger than Tampa. The group of Chiones to which Chione ef. C. trimeris belongs has not been reported earlier than the Chipola formation of Miocene age.

In a limestone quarry at locality 78 , about $1 \frac{1}{2}$ miles south-southwest of Belleview (pl. 12), solution pipes 5-10 feet deep in Ocala limestone are filled with dark-brown to green stiff clay containing phosphate pellets, manatee ribs, and large silicified oysters. Wilson has identified these oysters as Ostrea normalis Dall of Miocene (Hawthorn) age.

The Miocene Foraminifera, "Sorites" sp., was identified by Druid Wilson in sample X280 from a depth of $30-37$ feet in drill hole 27 (pl. 14). The Late Eocene Foraminifera Heterostegina ocalana Cushman, and species of orbitoids and camerinids, were found associated with "Sorites" sp. in sample X281 from a depth of 37-41.5 feet in drill hole 27.

The fossils cited above support the view that the beds of phosphorite, sand, and clay within the area of anomalous radioactivity are Miocene in age. Cooke (1945, p. 158-159) reached the same conclusion on the basis of the abundant float of very porous sandy phosphorite that 
occurs in these areas. He recognized this rock as the completely weathered remnant of phosphatic beds that he regarded as outliers of the Hawthorn formation. The outliers of Hawthorn formation, which he shows on the geologic map of Florida south of Ocala (Cooke, 1945, pl. 1), correspond closely to the areas of anomalous radioactivity here; larger outliers of the Hawthorn formation occur also northwest of Ocala but, the main outcrop belt of the formation is farther east and north of Ocala.

At various places in the canal cuts west of the areas of radioactive anomalies (pl. 12), tough clayey sand that is mottled red and orange by weathering rests upon Ocala limestone and is covered with loose light-yellow sand. This massive clayey sand is probably Miocene in age; it closely resembles clayey sand about 30 miles south of this area in Hernando and Pasco Counties that Cooke $(1945$, p. 153, 159) believes to be derived from the Hawthorn formation.

The Miocene sedimentary rocks rest uncomfortably upon the Ocala limestone in the Ocala area. The Suwannee limestone of Oligocene age, which is widespread in Hernando and Pasco Counties, is not known to be present here.

\section{PLEISTOCENE SEDIMENTS}

Some geologists working in the southeastern Coastal Plain have recognized ancient shorelines and terraces at various altitudes, and have concluded that the sea stood at higher levels during interglacial stages of the Pleistocene. The highest shoreline is regarded as the oldest, and each lower shoreline as being successively younger. Cooke (1945, p. 245-311) has recognized 7, and possibly 8, shorelines, with the highest at an altitude of 270 feet. MacNeil (1950) has recognized 4 Pleistocene shorelines in Florida, the highest being at 150 feet; he believes that Cooke's higher shorelines may be fluvial in origin rather than marine.

No ancient shorelines can be recognized with certainity in the Ocala area from study of the topographic maps or aerial photographs; but, as Cooke (1945, p. 285) has pointed out, ground-water solution of the Ocala limestone has modified the surface topography and may have obliterated such shorelines here. However, pebble deposits and sand deposits which may be beach deposits and are probably of Pleistocene age, are found at several places. Several hundred feet west of sample locality 94 (pl. 12), a gravel sheet composed of pebbles and cobbles of sandstone and leached sandy phosphorite is exposed in the roadbank between 115 and 135 feet altitude. Near the small radioactivity anomaly about 0.7 mile southeast of this exposure, similar gravels are exposed at two places along the road; the altitude at one locality is 
about 150 feet, and at the other locality about 125 feet. Bedded light-yellow sand with thin clayey layers several inches apart and containing charcoal fragments is exposed at altitudes of 70-80 feet in the canal cut 2-3 miles west of the area shown in plate 12. The bedded sand is as much as 8 feet thick; it overlies the mottled red and orange tough clayey sand of probable Miocene age, and lies beneath several feet of loose white and light-yellow sand that also contains charcoal fragments. This unbedded surficial sand may be windblown in origin; it is well exposed at altitudes of 80-100 feet in the canal cuts shown in plate 12 .

\section{STRUCTURE}

The report area is about 20 miles east of the axis of the Ocala uplift, an extensive northwestward trending anticline that is the major structural feature in the Eocene and younger formations in northern peninsular Florida. Northwestward-trending faults and irregular flexures occur on the anticline, according to Vernon (1951, pl. 2). His structural map suggests that the Miocene outliers south of Ocala may be preserved in a locally downwarped area.

None of these regional structural features was detected in the small area studied. Bedding in the Ocala limestone where exposed in quarries seems to be horizontal. A nearly vertical fault plane, with a more westerly trend than those shown by Vernon (1951), is exposed in the northwestern corner of a small abandoned quarry in the SW 1/4 sec. 25 , T. 15 S., R. 21 E. (pl. 12). The fault strikes between N. $80^{\circ}$ and $85^{\circ} \mathrm{W}$.; grooves and slickensides on the fault plane plunge $15^{\circ}-20^{\circ} \mathrm{W}$., indicating the major component of movement to have been horizontal. The nature of the slickensides suggests eastward movement of the northern block but the evidence is inconclusive.

\section{EFTECTS OF WEATHERING}

Ground-water leaching of the soluble constituents of the Ocala limestone and the Miocene sedimentary rocks has been very thorough and has been a dominant factor in the formation of the soils and topography in the area. The Ocala limestone is very permeable and contains little insoluble material; solution sinkholes have been widely formed in the limestone.

The Miocene sedimentary rocks, however, contain much insoluble material in the form of clay and sand, and they are less susceptible to leaching. The apatite pellets in the Miocene phosphorite commsuly have been rather resistant to weathering and are found scattered over the ground at many places. However, apatite pellets have been completely dissolved in some phosphorite to leave a very porous pumicelike sandstone with cavities relict from the pellets. Soils in the areas of Miocene sedimentary rocks are characteristically dark brown, and 
their composition ranges from loamy sand through sandy loam to sandy clay. A soil sample from about $1 \frac{1}{2}$ miles east-southeast of Ocala was found to contain 5.35 percent $\mathrm{P}_{2} \mathrm{O}_{5}$ (Sellards and others, 1915, p. 123). These soils support a distinctive native vegetation, including such deciduous trees as hickory, sweetgum, red oak, white oak, and maple (Sellards and others, 1915).

In all probability, a sheet of Miocene sedimentary rocks originally covered the Ocala limestone in this area. Stream erosion removed much of the Miocene rocks, but as the Ocala limestone was exposed, the surface drainage gradually changed from a stream system to a sinkhole system. All drainage now is by underground channels.

The areas of anomalous radioactivity for the most part have an altitude of 100 feet above sea level or higher, although considerable land above the 100-foot contour line is outside the radioactive areas. It would appear, therefore, that the altitude of the contact between the Ocala limestone and the Miocene rocks is about 100 feet above sea level at many places. However, this contact is extremely irregular probably because of both pre-Miocene erosion and solution of the Ocala limestone, and post-Miocene solution of the Ocala limestone accompanied by slumping of the Miocene sedimentary rocks.

About 0.6 mile northwest of Monroes Corner (pl. 12), the base of the Miocene strata was found at an altitude of about 54 feet in drill hole 25 , but is at least 66 feet lower in drill hole 28 on the edge of a sinkhole, 600 feet to the north. In many exposures of the Ocala limestone, solution pipes filled with residuum of Miocene rocks are evident. Ground-water solution of the Ocala limestone has resulted in random draping of the Miocene strata and their residuum into hollows and over hummocks in the limestone.

\section{DRILLING AND SAMPLING METHODS}

Areas of anomalous radioactivity were explored at 3 localities by 10 drill holes (total length of 335 feet) drilled by means of a jeep-mounted power auger. The auger bit cut readily through the unconsolidated phosphatic clayey and sandy beds, and also into soft Ocala limestone in several holes, but would not penetrate consolidated rock; probably the hard rock that stopped the drill in most holes was hard or silicified Ocala limestone, but in some holes it may have been hard phosphatic limestone of Miocene age.

Cuttings brought to the surface by continuous drilling with the auger provide poor samples because it is not possible to determine closely the depths from which the cuttings came. In order to reduce this uncertainty, the holes were drilled in 5-foot increments, and the drill rods were pulled out and the cuttings removed after each 5-foot run. Where drilling was above the water table, the cuttings from a 
5-foot interval usually filled the screws for a distance of 8-10 feet above the bit, and it was a simple matter to estimate depth of contacts. The surface of the mass of cuttings on the screws was usually coated with sand rubbed on from the sides of the hole as the rods were pulled up; before taking the sample off the rod, the sand was sliced off the cuttings over a width of several inches along the full length of one side of the rod, and about an ounce of material was then taken off every screw thread or every other screw thread throughout an interval of uniform lithology. Several holes were drilled into soft, watersoaked material that would slide off the screw flanges and yield very poor recovery of cuttings. Where recovery was good, it is believed that the lithologic logs made as the cuttings were taken off the rods are fairly reliable, because the highly phosphatic zones indicated by the cuttings generally correspond rather well with the strongly radioactive zones recorded by the scintillation detector (pls. 13, 14, and 15). It was not possible to $\log$ each hole with this instrument immediately after drilling, with the result that caving occurred in the lower parts of some holes, and only the uncaved parts of the holes could be logged with the scintillation detector.

\section{URANIFEROUS PHOSPHATIC MATERIALS}

The uraniferous phosphatic materials found in drilling consist of fresh, soft, phosphatic sediments (principally pellet phosphorites and phosphatic clays), and the highly weathered, leached residuum of these phosphatic sediments. Each of these classes of materials was also found in surface exposures or float. The general characteristics of these different phosphatic materials are described below.

\section{PELLET PHOSPHORITE}

Pellet phosphorite beds were cut in the auger drill holes 0.6 mile northwest of Monroes Corner (pl. 14) and in the drill holes about 214 miles east of this locality (pl. 13). The beds range from several feet to $14 \frac{1}{2}$ feet in thickness. The phosphorite is a light-gray to tan sandy clay that contains variable amounts of phosphate pellets. These pellets are well-rounded, usually less than half an inch in size, and are light colored with shiny surfaces; they are composed of apatite (carbonate-fluorapatite variety according to George Ashby, U. S. Geological Survey, oral communication, 1956) and contain inclusions of quartz grains.

The content of uranium, $\mathrm{P}_{2} \mathrm{O}_{5}$, and quartz in samples of pellet phosphorite is given in table 1 . Total $\mathrm{P}_{2} \mathrm{O}_{5}$ ranges from 3.1 to 20.8 percent, and total uranium ranges from 0.004 to 0.022 percent. No consistent relation exists between the total amount of uranium and 
the total amount of $\mathrm{P}_{2} \mathrm{O}_{5}$ in these samples. In several samples (X260, X296, and X297) high $\mathrm{P}_{2} \mathrm{O}_{5}$ content and high uranium content are associated, but in other samples high $\mathrm{P}_{2} \mathrm{O}_{5}$ content is accompanied by low uranium content (samples X280 and X281), and low $\mathrm{P}_{2} \mathrm{O}_{5}$ content is accompanied by high uranium content (samples $\mathrm{X} 266$ and $\mathrm{X} 277$ ).

Within the different size fractions of these samples, however, a rather consistent relation exists between the content of uranium and $\mathrm{P}_{2} \mathrm{O}_{5}$. Both $\mathrm{P}_{2} \mathrm{O}_{5}$ and uranium are most abundant in the +20 mesh fractions and the -150 mesh fractions. Between 80 and 90 percent of the total $\mathrm{P}_{2} \mathrm{O}_{5}$ and uranium in all but 1 sample (X270) is contained in these 2 size fractions together. The material between -20 mesh and +150 mesh in size consists largely of quartz sand. The +20 mesh fractions have a high content of apatite pellets; the percent of this size fraction in the different samples ranges from 3.3 to 40.8 percent. In the -150 mesh fractions, phosphate is presumably present as fine apatite, and is accompanied by clay and fine quartz. In samples with large +20 mesh fractions, most of the $\mathrm{P}_{2} \mathrm{O}_{5}$ and uranium are present in this coarse fraction, but in samples with small +20 mesh fractions, $\mathrm{P}_{2} \mathrm{O}_{5}$ and uranium are mainly in the -150 mesh fractions.

TABLE 1.-Uranium, $P_{2} O_{5}$, and quartz contents, in percent, of different size fractions of samples of pellet phosphorite from drill holes in the area south of Ocala, Marion County, Fla.

[Analysts: G. Daniels, G. Edgington, T. Murphy, R. Smith, A. Sweeney, and J. Waring, U. S. Geological Survey]

\begin{tabular}{|c|c|c|c|c|c|c|c|}
\hline \multirow{2}{*}{ Sample and fraction } & \multirow{2}{*}{$\begin{array}{l}\text { Ura- } \\
\text { nium }\end{array}$} & \multirow{2}{*}{$\mathrm{P}_{2} \mathrm{O}_{5}$} & \multirow{2}{*}{ Quartz ${ }^{1}$} & \multicolumn{4}{|c|}{ Percentage of total- } \\
\hline & & & & Sample & Uranium & $\mathrm{P}_{2} \mathrm{O}_{5}$ & Quartz \\
\hline $\begin{array}{l}\mathrm{X} 260 \text { (DH } 25,1.0-3.0 \text { feet): } \\
+20 \text { mesh } \\
\quad-20+48 \text { mesh } \\
-48+150 \text { mesh } \\
-150 \text { mesh. }\end{array}$ & $\begin{array}{r}0.019 \\
.009 \\
.005 \\
.014\end{array}$ & $\begin{array}{r}25.8 \\
12.4 \\
7.4 \\
12.5\end{array}$ & & $\begin{array}{r}38.1 \\
7.7 \\
7.4 \\
46.8\end{array}$ & $\begin{array}{r}48.7 \\
4.7 \\
2.5 \\
44.1\end{array}$ & $\begin{array}{r}57.2 \\
5.5 \\
3.2 \\
34.1\end{array}$ & (n) \\
\hline Entire sample........ & .015 & 17.1 & & 100.0 & 100.0 & 100.0 & - \\
\hline $\begin{array}{l}\mathrm{X} 266 \text { (DH25, } 17.0-21.0 \text { feet): } \\
+20 \text { mesh } \\
\quad-20+48 \text { mesh } \\
-48+150 \text { mesh } \\
-150 \text { mesh }\end{array}$ & $\begin{array}{r}0.031 \\
.008 \\
.002 \\
.027\end{array}$ & $\begin{array}{r}20.4 \\
5.4 \\
1.6 \\
8.9\end{array}$ & $\begin{array}{r}29.3 \\
79.6 \\
92.4 \\
3.5\end{array}$ & $\begin{array}{r}14.5 \\
9.5 \\
24.0 \\
52.0\end{array}$ & $\begin{array}{r}22.7 \\
3.9 \\
2.4 \\
71.0\end{array}$ & $\begin{array}{r}34.9 \\
6.0 \\
4.5 \\
54.6\end{array}$ & $\begin{array}{r}11.9 \\
21.1 \\
61.9 \\
5.1\end{array}$ \\
\hline Entire sample......... & .020 & 8.4 & 35.8 & 100.0 & 100.0 & 100.0 & 100,0 \\
\hline $\begin{array}{l}\mathrm{X} 270 \text { (DH26, } 4.5-7.5 \text { feet): } \\
+20 \text { mesh } \\
\quad-20+48 \text { mesh } \\
-48+150 \text { mesh } \\
-150 \text { mesh }\end{array}$ & $\begin{array}{r}0.010 \\
.004 \\
.002 \\
.005\end{array}$ & $\begin{array}{r}18.2 \\
7.8 \\
5.0 \\
8.7\end{array}$ & & $\begin{array}{r}3.3 \\
11.8 \\
25.0 \\
59.9\end{array}$ & $\begin{array}{r}7.7 \\
10.9 \\
11.7 \\
69.7\end{array}$ & $\begin{array}{r}7.5 \\
11.5 \\
15.7 \\
65.3\end{array}$ & \\
\hline Entire sample... & .004 & 8. 0 & & 100.0 & 100.0 & 100.0 & $\ldots$ \\
\hline
\end{tabular}

See footnote at end of table. 
TABLE 1.-Uranium, $P_{2} \mathrm{O}_{5}$, and quartz contents, in percent, of different size fractions of samples of pellet phosphorite from drill holes in the area south of Ocala, Marion County, Fla.-Continued

\begin{tabular}{|c|c|c|c|c|c|c|c|}
\hline \multirow{2}{*}{ Sample and fraction } & \multirow{2}{*}{$\begin{array}{l}\text { Ura- } \\
\text { nium }\end{array}$} & \multirow{2}{*}{$\mathrm{P}_{2} \mathrm{O}_{8}$} & \multirow{2}{*}{ Quartz 1} & \multicolumn{4}{|c|}{ Percentage of total- } \\
\hline & & & & Sample & Uranium & $\mathrm{P}_{2} \mathrm{O}_{5}$ & Quartz \\
\hline $\begin{array}{l}\text { X272 (DH } 26,12.0-16.0 \text { feet): } \\
+20 \text { mesh } \\
\quad-20+48 \text { mesh } \\
-48+150 \text { mesh } \\
-150 \text { mesh }\end{array}$ & $\begin{array}{r}0.018 \\
.007 \\
.003 \\
.002\end{array}$ & $\begin{array}{r}28.2 \\
13.2 \\
6.6 \\
5.9\end{array}$ & $\begin{array}{l}18.2 \\
54.1 \\
77.5 \\
14.6\end{array}$ & $\begin{array}{r}18.5 \\
3.9 \\
11.3 \\
66.3\end{array}$ & \begin{tabular}{r|}
63.2 \\
5.2 \\
6.4 \\
25.2
\end{tabular} & $\begin{array}{r}50.2 \\
5.0 \\
7.1 \\
37.7\end{array}$ & $\begin{array}{r}14.1 \\
8.9 \\
36.5 \\
40.5\end{array}$ \\
\hline Entire sample_... & .005 & 10.3 & 23.9 & 100.0 & 100.0 & 100.0 & 100.0 \\
\hline $\begin{array}{l}\mathrm{X} 276 \text { (DH27, } 9.0-17.5 \text { feet): } \\
\quad+20 \text { mesh } \\
\quad-20+48 \text { mesh } \\
-48+150 \text { mesh. } \\
\quad-150 \text { mesh.... }\end{array}$ & $\begin{array}{r}0.015 \\
.007 \\
.001 \\
.017\end{array}$ & $\begin{array}{r}11.7 \\
2.3 \\
0.6 \\
4.9\end{array}$ & . & $\begin{array}{r}5.4 \\
10.6 \\
43.1 \\
40.9\end{array}$ & \begin{tabular}{r|}
9.2 \\
8.3 \\
4.8 \\
77.7
\end{tabular} & $\begin{array}{r}20.3 \\
7.8 \\
8.2 \\
63.7\end{array}$ & (n) \\
\hline Entire sample_.. & .009 & 3.1 & $\ldots$ & 100.0 & 100.0 & 100.0 & $-\ldots$ \\
\hline $\begin{array}{l}\mathrm{X} 277 \text { (DH27, } 17.5-21.0 \text { feet): } \\
+20 \text { mesh... } \\
\quad-20+48 \text { mesh } \\
-48+150 \text { mesh } \\
-150 \text { mesh }\end{array}$ & $\begin{array}{r}0.020 \\
.012 \\
.001 \\
.039\end{array}$ & $\begin{array}{r}14.0 \\
3.9 \\
1.4 \\
7.4\end{array}$ & $\begin{array}{r}35.8 \\
75.1 \\
93.2 \\
4.3\end{array}$ & $\begin{array}{r}8.2 \\
10.8 \\
31.8 \\
49.2\end{array}$ & $\begin{array}{r}7.4 \\
5.7 \\
1.4 \\
85.5\end{array}$ & $\begin{array}{r}20.4 \\
7.4 \\
7.9 \\
64.3\end{array}$ & $\begin{array}{r}6.9 \\
18.9 \\
69.3 \\
4.9\end{array}$ \\
\hline Entire sample... & .022 & 5.6 & 42.8 & 100.0 & 100.0 & 100.0 & 100.0 \\
\hline $\begin{array}{l}\text { X280 (DH27, 30.0-37.0 feet): } \\
+20 \text { mesh } \\
\quad-20+48 \text { mesh } \\
-48+150 \text { mesh } \\
-150 \text { mesh }\end{array}$ & $\begin{array}{r}0.005 \\
.005 \\
.003 \\
.006\end{array}$ & $\begin{array}{r}30.2 \\
17.8 \\
9.1 \\
17.1\end{array}$ & $\begin{array}{l}44.9 \\
71.8 \\
12.1\end{array}$ & $\begin{array}{l}37.7 \\
11.0 \\
15.3 \\
36.0\end{array}$ & $\begin{array}{r}37.3 \\
10.9 \\
9.1 \\
42.7\end{array}$ & $\begin{array}{r}54.5 \\
9.4 \\
6.7 \\
29.4\end{array}$ & (1) \\
\hline Entire sample... & .005 & 20.8 & ....... & 100.0 & 100.0 & 100.0 & - \\
\hline $\begin{array}{l}\text { X281 (DH27, } 37.0-41.5 \text { feet): } \\
+20 \text { mesh } \\
\quad-20+48 \text { mesh } \\
-48+150 \text { mesh } \\
-150 \text { mesh }\end{array}$ & $\begin{array}{r}0.006 \\
.005 \\
.002 \\
.004\end{array}$ & $\begin{array}{l}27.9 \\
21.1 \\
11.0 \\
15.2\end{array}$ & $\mid-1-1-1$ & $\begin{array}{l}40.8 \\
11.0 \\
12.2 \\
36.0\end{array}$ & $\begin{array}{r}52.3 \\
11.8 \\
5.2 \\
30.7\end{array}$ & $\begin{array}{r}55.4 \\
11.3 \\
6.6 \\
26.7\end{array}$ & (n) \\
\hline Entire sample.... & .005 & 20.5 & ……. & 100.0 & 100.0 & 100.0 & -... \\
\hline $\begin{array}{r}\text { X290 (DH28, } 40.0-43.5 \text { feet): } \\
+20 \text { mesh } \\
-20+48 \text { mesh } \\
-48+150 \text { mesh } \\
-150 \text { mesh........ }\end{array}$ & $\begin{array}{l}0.014 \\
.005 \\
.001 \\
.002\end{array}$ & $\begin{array}{r}23.5 \\
10.7 \\
2.0 \\
3.5\end{array}$ & $\begin{array}{r}15.5 \\
44.8 \\
90.6 \\
5.2\end{array}$ & $\begin{array}{r}29.9 \\
4.7 \\
45.6 \\
19.8\end{array}$ & $\begin{array}{r}79.4 \\
4.5 \\
8.6 \\
7.5\end{array}$ & $\begin{array}{r}76.9 \\
5.5 \\
10.0 \\
7.6\end{array}$ & $\begin{array}{r}9.4 \\
4.3 \\
84.2 \\
2.1\end{array}$ \\
\hline Entire sample.... & .005 & 9.1 & 49.1 & 100.0 & 100.0 & 100.0 & 100.0 \\
\hline $\begin{array}{r}\text { X296 (DH29, } 4.5-7.5 \text { feet): } \\
+20 \text { mesh } \\
-20+48 \text { mesh } \\
-48+150 \text { mesh } \\
-150 \text { mesh........ }\end{array}$ & $\begin{array}{r}0.021 \\
.010 \\
.003 \\
.018\end{array}$ & $\begin{array}{r}26.9 \\
11.6 \\
4.8 \\
12.5\end{array}$ & $\begin{array}{r}12.7 \\
55.2 \\
82.8 \\
6.5\end{array}$ & $\begin{array}{r}34.5 \\
9.0 \\
27.1 \\
29.4\end{array}$ & $\begin{array}{r}50.8 \\
6.3 \\
5.7 \\
37.2\end{array}$ & $\begin{array}{r}60.6 \\
6.9 \\
8.5 \\
24.0\end{array}$ & $\begin{array}{r}13.0 \\
14.8 \\
66.6 \\
5.6\end{array}$ \\
\hline Entire sample.......... & .014 & 15. 2 & 33.7 & 100.0 & 100.0 & 100.0 & 100.0 \\
\hline $\begin{array}{r}\mathrm{X} 297 \text { (DH29, } 7.5-9.0 \text { feet): } \\
+20 \text { mesh } \\
\quad-20+48 \text { mesh } \\
-48+150 \text { mesh } \\
-150 \text { mesh. }\end{array}$ & $\begin{array}{l}0.023 \\
.011 \\
.004 \\
.015\end{array}$ & $\begin{array}{r}27.3 \\
15.6 \\
4.8 \\
12.3\end{array}$ & $\begin{array}{r}14.5 \\
50.4 \\
82.4 \\
3.2\end{array}$ & $\begin{array}{r}20.3 \\
3.1 \\
12.1 \\
64.5\end{array}$ & $\begin{array}{r}30.8 \\
2.2 \\
3.2 \\
63.8\end{array}$ & $\begin{array}{r}38.1 \\
3.3 \\
4.0 \\
54.6\end{array}$ & $\begin{array}{r}17.8 \\
9.4 \\
60.5 \\
12.3\end{array}$ \\
\hline Entire sample..... & .015 & 14.5 & 16. 5 & 100.0 & 100.0 & 100.0 & 100.0 \\
\hline
\end{tabular}

1 Quartz in +20 mesh fractions consists mostly of grains included in phosphate pellets. 
The uranium, $\mathrm{P}_{2} \mathrm{O}_{5}$, and quartz contents of samples of what appears to be the same phosphorite bed in 4 different drill holes are compared in table 2. This bed ranges from $3 \frac{11}{2}$ to $4 \frac{1}{2}$ feet in thickness, and is underlain by a bed of clay (pl. 14). In drill hole 28 a phosphorite bed $14 \frac{1}{2}$ feet thick may be the same bed that has been thickened by flowage or slumping into a sinkhole. The variation in composition of this bed within short distances is very marked. Percent $\mathrm{P}_{2} \mathrm{O}_{5}$ ranges from 5.6 to 15.0 , percent uranium from 0.005 to 0.022 , and percent quartz from 23.9 to 42.8 ; percent of +20 mesh fraction ranges from 8.3 to 29.7 , and percent of -150 mesh fraction from 41.1 to 66.4 .

TABLE 2.-Uranium, $P_{2} O_{5}$, and quartz contents, in percent, of samples of pellet phosphorite from the same $(?)$ bed in four different drill holes in the area south of Ocala, Marion County, Fla.

[Analysts: G. Edgington, R. Smith, A. Sweeney, and J. Waring, U. S. Geological Survey]

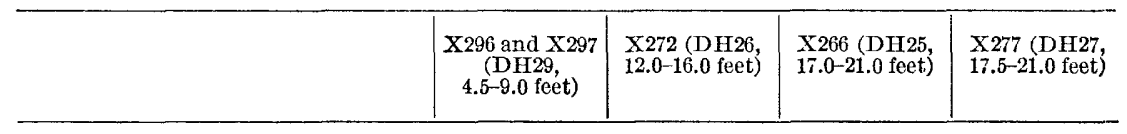

Entire sample

\begin{tabular}{|c|c|c|c|c|}
\hline $\begin{array}{l}\text { Uranium } \\
\mathrm{P}_{2} \mathrm{O}_{5} \\
\mathrm{Quartz}\end{array}$ & $\begin{array}{l}0.014 \\
15.0 \\
28.0\end{array}$ & $\begin{array}{l}0.005 \\
10.3 \\
23.9\end{array}$ & $\begin{array}{l}0.020 \\
8.4 \\
35.8\end{array}$ & $\begin{array}{l}0.022 \\
5.6 \\
42.8\end{array}$ \\
\hline
\end{tabular}

\begin{tabular}{|c|c|c|c|c|}
\hline \multicolumn{5}{|c|}{+20 mesh fraction } \\
\hline $\begin{array}{l}\text { Uranium } \\
\mathrm{P}_{2} \mathrm{O}_{5} \\
\text { Quartz (nearly all included in phos- } \\
\text { phate pellets) } \\
\text { Percentage of total } \\
\quad \text { Sample } \\
\quad \text { Uranium } \\
\quad \mathrm{P}_{2} \mathrm{O}_{5} \\
\quad \text { Quartz }\end{array}$ & $\begin{array}{l}0.022 \\
27.0 \\
13.3 \\
29.7 \\
44.1 \\
53.1 \\
14.6\end{array}$ & $\begin{array}{l}0.018 \\
28.2 \\
18.2 \\
18.5 \\
63.2 \\
50.2 \\
14.1\end{array}$ & $\begin{array}{l}0.031 \\
20.4 \\
29.3 \\
14.5 \\
22.7 \\
34.9 \\
11.9\end{array}$ & $\begin{array}{r}0.020 \\
14.0 \\
35.8 \\
8.2 \\
7.4 \\
20.4 \\
6.9\end{array}$ \\
\hline
\end{tabular}

-150 mesh fraction

\begin{tabular}{|c|c|c|c|c|}
\hline $\begin{array}{l}\text { Uranium } \\
\mathrm{P}_{2} \mathrm{O}_{5} \\
\mathrm{Quartz}_{2}\end{array}$ & $\begin{array}{l}0.017 \\
12.4 \\
5.4\end{array}$ & $\begin{array}{l}0.002 \\
5.9 \\
14.6\end{array}$ & $\begin{array}{l}0.027 \\
8.9 \\
3.5\end{array}$ & $\begin{array}{l}0.039 \\
7.4 \\
4.3\end{array}$ \\
\hline $\begin{array}{l}\text { Percentage of total- } \\
\text { Sample.... } \\
\text { Uranium } \\
\mathrm{P}_{2} \mathrm{O}_{5} \\
\text { Quartz }\end{array}$ & $\begin{array}{r}41.1 \\
46.0 \\
34.2 \\
7.9\end{array}$ & $\begin{array}{l}66.3 \\
25.2 \\
37.7 \\
40.5\end{array}$ & $\begin{array}{r}52.0 \\
71.0 \\
54.6 \\
5.1\end{array}$ & $\begin{array}{r}49.2 \\
85.5 \\
64.3 \\
4.9\end{array}$ \\
\hline
\end{tabular}

+20 mesh and -150 mesh fractions combined

\begin{tabular}{|c|c|c|c|c|}
\hline $\begin{array}{l}\text { Percentage of total- } \\
\text { Sample } \\
\text { Uranium } \\
\mathrm{P}_{2} \mathrm{O}_{5}\end{array}$ & $\begin{array}{l}70.8 \\
90.1 \\
87.3\end{array}$ & $\begin{array}{l}84.8 \\
88.4 \\
87.9\end{array}$ & $\begin{array}{l}66.5 \\
93.7 \\
89.5\end{array}$ & $\begin{array}{l}57.4 \\
92.9 \\
84.7\end{array}$ \\
\hline
\end{tabular}




\section{CLAY}

Beds of stiff green clay, 2-9 feet thick, were cut in most of the drill holes (pls. 13, 14, and 15). Small white phosphate particles are commonly present in the clay. The percent $\mathrm{P}_{2} \mathrm{O}_{5}$ ranges from 3.5 to 9.8 , and percent uranium from 0.001 to 0.006 (table 3 ). The mode of occurrence of uranium was not determined; it is not known whether uranium is associated only with apatite, or whether some uranium may be associated with the clay minerals. Considerable fine-grained quartz occurs in the clay; some of the samples that are reported to have more than 20 percent quartz may have been contaminated by adhering loose sand that was not completely removed when the sample was taken.

TABLE 3.-Uranium, $P_{2} \mathrm{O}_{5}$, and quartz contents, in percent, of samples of clay from drill holes in the area south of Ocala, Marion County, Fla.

]Analysts: G. Daniels, M. Delevaux, T. Murphy, D. Riska, R. Smith, A. Sweeney, W. Tucker, and J. Waring, U. S. Geological Survey]

\begin{tabular}{|c|c|c|c|}
\hline Sample & Uranium & $\mathrm{P}_{2} \mathrm{O}_{5}$ & Quartz \\
\hline $\begin{array}{l}\text { X245 (DH21, 6.2-10.0 feet) } \\
\text { X246 (DH21, } 10.0-11.0 \text { feet) } \\
\text { X250 (DH22, } 10.5-13.5 \text { feet) } \\
\text { X251 (DH22, } 13.5-17.5 \text { feet) } \\
\text { X258 (DH24, 5.0-11.5 feet) } \\
\text { X261 (DH25, 3.0-4.8 feet) } \\
\text { X263 (DH25, 6.0 } 9.0 \text { feet) } \\
\text { X265 (DH25, } 12.0-17.0 \text { feet) } \\
\text { X267 (DH25, 21.0-23.0 feet) } \\
\text { X271 (DH26, 7.5-12.0 feet) } \\
\text { X273 (DH26, 16.0-17 } 5 \text { feet) } \\
\text { X278 (DH27, 21.0-27.0 feet) } \\
\text { X279 (DH27, 27.0-30.0 feet) } \\
\text { X293 (DH28, 54.5-60.5 feet) } \\
\text { X298 (DH29, 9.0-13 } 5 \text { feet) } \\
\text { X309 (DH30, } 34.5-43.5 \text { feet) }\end{array}$ & $\begin{array}{l}0.002 \\
.001 \\
.002 \\
.001 \\
.002 \\
.001 \\
.002 \\
.006 \\
.003 \\
.002 \\
.004 \\
.002 \\
.001 \\
.001 \\
.001 \\
.001\end{array}$ & $\begin{array}{l}5.6 \\
4.3 \\
7.0 \\
7.2 \\
5.1 \\
5.8 \\
4.3 \\
7.3 \\
7.1 \\
6.1 \\
8.3 \\
9.8 \\
4.1 \\
4.1 \\
5.9 \\
3.5\end{array}$ & \begin{tabular}{r}
25.8 \\
16.2 \\
26.7 \\
30.0 \\
16.9 \\
28.7 \\
10.1 \\
11.4 \\
12.4 \\
20.9 \\
20.1 \\
\hdashline 9.2 \\
21.8 \\
23.6
\end{tabular} \\
\hline
\end{tabular}

$1 \mathrm{X} 251$ also has 10.4 percent $\mathrm{CaO}, 9.5$ percent total $\mathrm{Al}_{2} \mathrm{O}_{3}, 7.8$ percent soluble $\mathrm{Al}_{2} \mathrm{O}_{3}$. X-ray powder diffraction analysis of -250 mesh fraction of X251 showed quartz, a montmorillonite minera!, attapulgite, and apatite.

\section{LEACHED PHOSPHORITE}

White to gray very porous sandy rock with numerous ovoid cavities forms abundant float at many places in the areas of abnormal radioactivity. This float was originally more widely distributed than it is now; much of it has been gathered into piles of field stone, or used to build walls, chimneys, or foundations. The material makes a good building stone, because it commonly occurs as massive blocks several feet in size, and can be readily sawed or cut.

The rock is composed mainly of quartz grains held together by a white cement in a cavernous or honey-combed structure. Ovoid cavities containing a little sand or claylike material are obviously relict from dissolved apatite pellets; partly decomposed pellets are still present in some cavities. The rock is the end product of weather- 
ing of clayey, sandy, pellet phosphorite, such as the beds that were cut in drill holes 25-29 (pl. 14). Minor amounts of compact phosphatic sand with low porosity are found with the vesicular rock; this compact rock was derived probably from sandy-clayey phosphorite that did not contain large apatite pellets.

Partial chemical analyses of surface samples of leached phosphorite are given in table 4 . Samples of very porous leached phosphorite are rather uniform in composition, with $\mathrm{P}_{2} \mathrm{O}_{5}$ ranging from 12.7 to 16.8 percent, uranium from 0.019 to $0.023, \mathrm{Al}_{2} \mathrm{O}_{3}$ from 14.7 to 20.0 , and quartz from 40.1 to 54.1 ; specific gravity of the rock is about 1 . The compact leached sandy phosphorite is more variable in composition; a sample (82) containing apatite pellets has less $\mathrm{Al}_{2} \mathrm{O}_{3}$ and much more $\mathrm{CaO}$ than samples of the highly leached material.

The samples of leached phosphorite from the drill holes differ somewhat in composition from'the samples of leached phosphorite from surface outcrops; $\mathrm{P}_{2} \mathrm{O}_{5}$ content is lower in all the drill-hole samples,

TABLE 4.-Uranium, $\mathrm{P}_{2} \mathrm{O}_{5}, \mathrm{Al}_{2} \mathrm{O}_{3}, \mathrm{CaO}$, and quartz contents, in percent, of samples of leached phosphorite from surface outcrops and float in the area south of Ocala, Marion County, Fla.

[Analysts: R. Moore, R. Smith, A. Sweeney, and W. Tucker, U. S. Geological Survey]

\begin{tabular}{l|c|c|c|c|c|c|c}
\hline Sample & $\begin{array}{c}\text { Specific } \\
\text { gravity }\end{array}$ & Uranium & $\mathrm{P}_{2} \mathrm{O}_{5}$ & $\begin{array}{c}\mathrm{Al}_{2} \mathrm{O}_{3} \\
\text { (total) }\end{array}$ & $\begin{array}{c}\mathrm{Al}_{2} \mathrm{O}_{3} \\
\text { (soluble) }\end{array}$ & $\mathrm{CaO}$ & Quartz \\
\hline
\end{tabular}

Very porous leached phosphorite

\begin{tabular}{|c|c|c|c|c|c|c|c|}
\hline $\begin{array}{l}83 \\
84 \\
87 \\
94 \\
97 \\
\mathrm{C}\end{array}$ & $\begin{array}{r}0.9-1.0 \\
<1.0 \\
1.2 \\
1.9 \\
1.0\end{array}$ & $\begin{array}{r}0.023 \\
.021 \\
.022 \\
.020 \\
.020 \\
.019\end{array}$ & $\begin{array}{l}16.8 \\
15.5 \\
15.4 \\
12.7 \\
13.7 \\
14.6\end{array}$ & $\begin{array}{l}20.0 \\
17.2 \\
16.1 \\
16.0 \\
14.7\end{array}$ & $\begin{array}{l}18.3 \\
16.3 \\
15.5 \\
14.2 \\
13.5\end{array}$ & $\begin{array}{r}1.24 \\
.73 \\
.90 \\
2.82 \\
.34\end{array}$ & $\begin{array}{l}40.1 \\
47.6 \\
50.8 \\
47.1 \\
54.1\end{array}$ \\
\hline
\end{tabular}

Compact leached sandy phosphorite

\begin{tabular}{|c|c|c|c|c|c|c|c|}
\hline $82 \ldots$ & $\begin{array}{r}1.3-1.4 \\
1.8 \\
1.5\end{array}$ & $\begin{array}{l}.016 \\
.006 \\
.017\end{array}$ & $\begin{array}{r}15.9 \\
6.6 \\
15.0\end{array}$ & $\begin{array}{r}7.9 \\
13.8 \\
17.2\end{array}$ & $\begin{array}{r}7.2 \\
9.7 \\
15.7\end{array}$ & $\begin{array}{r}18.8 \\
.17 \\
2.59\end{array}$ & $\begin{array}{l}42.3 \\
58.4 \\
42.8\end{array}$ \\
\hline
\end{tabular}

Description and location of sumples:

82. Composite sample from boulders of white phosphatic sandstone containing phosphate pellets; from the NW1/4NE1/4 sec. 10, T. 17 S., R. 22 E., Marion County, Fla.

83. Composite sample of porous leached phosphorite containing a few relict phosphate pellets; from the SW1/4NE1/4 sec. 3 , T. 17 S., R. 22 E., Marion County, Fla.

84. Composite sample of very porous leached phosphorite; from the NW1/4 SE $\frac{1}{4} / 4$ sec. $4, T$, 17 S., R $22 \mathrm{E}$., Marion County, Fla.

85. Composite sample of compact sandy-clayey phosphorite; from the NW1/4SE1/4 sec. 4, T. $17 \mathrm{~S}$., R.

87. Composite sample of very porous leached phosphorite; from the NW1/4 sec. 4, T. 17 S., R. 22 E.,
. Marion County, Fla.

89. Composite sample of sandy phosphorite with soft white phosphate pellets; from the SE1/4 SE1/4 see. 5, T. 17 S., R. 22 E., Marion County, Fla.

94. Composite sample of very porous leached phosphorite; from center of south edge of sec. $1, T .16 \mathrm{~S}$., R. 21 E., Marion County, Fla.

97. Composite sample of very porous leached phosphorite; from the SE1/4NW1/4 sec. 1, T. 16 S., R. 21 E.,

Marion County, Fla. Sample taken by J. B. Catheart (see Cathcart, 1954) of "outcrop of aluminum phosphate zone" in sec. 11, T. 16 S., R. 21 E., Marion County, Fla. 
and in 3 samples from 1 drill hole (DH21, table 5) the uranium content is lower. Minerals present in the -250 mesh fractions of 2 drillsamples were determined by X-ray powder diffraction methods to be wavellite, crandallite (pseudowavellite), kaolinite, and quartz. The mineralogy, as well as the physical appearance, of the leached porous phosphorite of this area resembles that of the aluminum phosphate rock of the "leached zone" of the Bone Valley formation of the landpebble phosphate field, about 85 miles south of Ocala (Altschuler, Jaffee, and Cuttitta, 1956).

TABLE 5.-Uranium, $\mathrm{P}_{2} \mathrm{O}_{5}, \mathrm{Al}_{2} \mathrm{O}_{3}, \mathrm{CaO}$, and quartz contents, in percent, of samples of leached phosphorite from drill holes in the area south of Ocala, Marion County, Fla.

[Analysts: G. Daniels, M. Delevaux, G. Edgington, T. Murphy, D. Riska, R. Smith, A. Sweeney, W. Tucker, and J. Waring, U. S. Geological Survey]

\begin{tabular}{|c|c|c|c|c|c|c|}
\hline Sample & $\begin{array}{l}\text { Ura- } \\
\text { nium }\end{array}$ & $\mathrm{P}_{2} \mathrm{O}_{5}$ & $\begin{array}{l}\mathrm{Al}_{2} \mathrm{O}_{3} \\
\text { (total) }\end{array}$ & $\begin{array}{c}\mathrm{Al}_{2} \mathrm{O}_{3} \\
\text { (soluble) }\end{array}$ & $\mathrm{CaO}$ & Quartz \\
\hline $\begin{array}{l}\text { X242 (DH21, 1.0-2.5 feet) } \\
\text { X243 (DH21, } 2.5-3.5 \text { feet) } \\
\text { X244 (DH21, 3.5-5.7 feet) } \\
\text { X249 (DH22, 1.0-10.5 feet) } \\
\text { X307 (DH30, 23.5-30.5 feet) }\end{array}$ & $\begin{array}{l}0.008 \\
.004 \\
.006 \\
.026 \\
.017\end{array}$ & $\begin{array}{l}6.3 \\
6.6 \\
5.4 \\
8.7 \\
3.3\end{array}$ & $\begin{array}{r}8.8 \\
13.8\end{array}$ & $\begin{array}{r}7.5 \\
10.6\end{array}$ & $\begin{array}{l}1.80 \\
0.11\end{array}$ & \begin{tabular}{r}
64.8 \\
68.1 \\
\hdashline-1 \\
-2
\end{tabular} \\
\hline
\end{tabular}

Uranium and $\mathrm{P}_{2} \mathrm{O}_{5}$ contents in different size fractions of sample $\mathrm{X} 307$

\begin{tabular}{|c|c|c|c|c|c|}
\hline \multirow{2}{*}{ Size fraction } & \multirow{2}{*}{ Uranium } & \multirow{2}{*}{$\mathbf{P}_{2} \mathrm{O}_{5}$} & \multicolumn{3}{|c|}{ Percentage of total- } \\
\hline & & & Sample & Uranium & $\mathrm{P}_{2} \mathrm{O}_{5}$ \\
\hline $\begin{array}{l}+20 \text { mesh } \\
-20+48 \text { mesh } \\
-48+150 \text { mesh } \\
-150 \text { mesh. }\end{array}$ & $\begin{array}{r}0.018 \\
.005 \\
.002 \\
.056\end{array}$ & $\begin{array}{r}12.5 \\
2.3 \\
0.5 \\
7.4\end{array}$ & $\begin{array}{r}8.3 \\
8.8 \\
58.9 \\
24.0 \\
\end{array}$ & $\begin{array}{r}9.0 \\
2.7 \\
7.1 \\
81.2 \\
\end{array}$ & $\begin{array}{r}31.3 \\
6.1 \\
8.9 \\
53.7 \\
\end{array}$ \\
\hline Entire sample. & .017 & 3.3 & 100.0 & 100.0 & 100.0 \\
\hline
\end{tabular}

${ }^{1}$ Analyses of -250 mesh fractions of X243 and X249 by X-ray powder diffraction methods showed wavellite, crandallite (pseudowavellite), kaolinite, and quartz.

\section{CONCLUSIONS}

The areas of abnormal radioactivity south of Ocala are related to thin beds of uraniferous phosphorite in outliers of Miocene rocks. Much of the radioactivity is probably derived from outcrops and float of leached porous phosphorite that is similar in appearance and composition to the aluminum phosphate rock of the "leached zone" of the Bone Valley formation. Abnormal radioactivity at some places in the Ocala area is caused by unleached, uraniferous pellet phosphorite. 


\section{REFERENCES CITED}

Altschuler, Z. S., Jaffe, E. B., and Cuttitta, Frank, 1956, The aluminum phosphate zone of the Bone Valley formation, Florida, and its uranium deposits, in Page, Stocking, and Smith, Contributions to the geology of uranium and thorium by the United States Geological Survey and Atomic Energy Commission for the United Nations International Conference on Peaceful Uses of Atomic Energy, Geneva, Switzerland, 1955: U. S. Geol. Survey Prof. Paper 300, p. 495-504.

Cathcart, J. B., 1954, Drilling of airborne radioactivity anomalies in Florida, Georgia, and South Carolina-1954: U. S. Geol. Survey open-file report.

Cooke, C. W., 1945, Geology of Florida: Fla. Geol. Survey Bull. 29.

MacNeil, F. S., 1950, Pleistocene shore lines in Florida and Georgia: U. S. Geol. Survey Prof. Paper 221-F.

Matson, G. C., 1915, The phosphate deposits of Florida: U. S. Geol. Survey Bull. 604.

Moxham, R. M., 1954, Airborne radioactivity surveys for phosphate in Florida: U. S. Geol. Survey Circ. 230.

Sellards, E. H., and others, 1915, Natural resources survey of an area in central Florida, including a part of Marion, Levy, Citrus, and Sumter Counties: Fla. Geol. Survey, 7th Ann. Rept., p. 117-251.

Vernon, R. O., 1951, Geology of Citrus and Levy Counties, Florida: Fla. Geol. Survey Bull. 33. 
